\title{
MATALAN KYNNYKSEN KOHTAAMISPAIKKOJEN SIJAINTI JA SAATAVUUS HELSINGIN KAUPUNGINOSISSA
}

Tuija Seppälä: VTT, Helsingin yliopisto

Henrietta Grönlund: TT, Helsingin yliopisto

Teemu Kemppainen: VTT, Helsingin yliopisto; Centre Maurice Halbwachs

tuija.seppala@helsinki.fi; henrietta.gronlund@helsinki.fi; teemu.t.kemppainen@belsinki.fi

Janus vol. 28 (2) 2020, 115-132

\section{(J) J a II \&}

\section{Tiivistelmä}

Tarkastelemme tässä tutkimuksessa eri toimijoiden ylläpitämiä matalan kynnyksen kohtaamispaikkoja, joita pidetään osallisuustyön keskeisinä areenoina. Tutkimuksemme tehtävänä on kartoittaa Helsingissä toimivat kohtaamispaikat ja tarkastella niiden sijaintia ja saatavuutta kaupunginosatasolla sosioekonomisen huono-osaisuuden näkökulmasta. Tutkimuksen aineisto koostuu kaupunginosia koskevasta tilastotiedosta, kohtaamispaikkojen osoitetiedoista sekä kohtaamispaikoille suunnatusta kyselystä. Kuvailevien analyysien mukaan kohtaamispaikat sijaitsevat useammin sosioekonomisesti huono-osaisemmilla alueilla. Toisaalta palveluiden määrä suhteessa sosioekonomisesti huonoosaisten määrään on näillä alueilla kaikkein pienin. Kohtaamispaikkojen sijaintia selittäviä tekijöitä tarkastelimme Poisson-regressioanalyysin avulla. Täydessä mallissa vakioimme ikääntyvän väestön osuuden ja selittävinä tekijöinä tarkastelimme sosioekonomista huono-osaisuutta, asukasmäärää, kulkuyhteyksiä sekä hintatasoa. Tulostemme mukaan kohtaamispaikkojen määrä kasvaa sosioekonomisen huono-osaisuuden, väkimäärän mutta myös hintatason myötä.

\section{JOHDANTO}

Viime vuosina on keskusteltu runsaasti haavoittuvassa asemassa olevien ryhmien osallisuuden lisäämisestä ja syrjäytymisen ehkäisystä. Keskustelu liittyy eritoten työttömyyden ja pitkäaikaistyöttömyyden kasvuun, mutta myös esimerkiksi toimeentulotuen tarpeen lisääntymiseen, demokratiakehitykseen sekä koetun yksinäisyyden laajuuteen. Osallisuuden lisäämistä ja syrjäytymisen ehkäisyä on tavoiteltu niin sanotun osallisuustyön avulla. Osallisuustyön tavoitteena on ollut yhtäältä työelämän ulkopuolella olevien työikäisten työelämäosallisuuden edistäminen erilaisten aktivointitoimenpiteiden, kuten kuntouttavan työtoiminnan, avulla (Karjalainen \& Saikku 2016; Raivio \&

Karjalainen 2013). Toisaalta aktivointitoimenpiteiden työelämäosallisuutta lisäävät vaikutukset ovat useiden tutkimusten mukaan olleet vähäisiä ja osallistumisella on nähty olevan enemmän sosiaalipoliittisia kuin työvoimapoliittisia vaikutuksia (esim. Elonen ym. 2017; Mäntyneva \& Hiilamo 2018). Sosiaalipoliittiset tavoitteet onkin nostettu osallisuustyön työvoimapoliittisten tavoitteiden rinnalle (Blomgren ym. 2016; Saikku 2018; Sosiaali- ja terveysministeriö 2015). Tämä on tarkoittanut toimintamahdollisuuksien tarjoamista sekä sosiaalisen osallisuuden ja vaikutusmahdollisuuksien tukemista ilman työelämäosallisuuden tavoitetta (esim. Isola ym. 2017). 
Osallisuustyön keskeisiksi areenoiksi on useissa yhteyksissä nostettu erilaiset matalan kynnyksen kohtaamispaikat (Isola ym. 2017; Karjalainen \& Saikku 2016; Leemann \& Hämäläinen 2016). Nämä ovat eri toimijoiden ylläpitämiä maksuttomia puolijulkisia tiloja, joissa toimintaan osallistumisen kynnys pyritään pitämään matalana niin, etteivät esimerkiksi taloudelliset tai sosiaaliset tekijät estäisi ihmisiä osallistumasta. Paikoissa pyritään korostetusti asiakaslähtöisyyteen, asiakkaan arvostamiseen ja ilmiöiden ymmärtämiseen tinkien esimerkiksi päihteettömyys- tai kansalaisuusvaatimuksista. Niissä voi usein käydä anonyymisti ja ilman lähetettä, eikä sitoutumista tai jäsenyyttä edellytetä. (Leemann \& Hämäläinen 2016; Törmä 2007.) Kohtaamispaikat tarjoavat mahdollisuuksia viettää aikaa toisten seurassa sekä tilaisuuksia vapaaehtoistoimintaan, vertaistukeen, kuntouttavaan työtoimintaan ja yhteiskunnalliseen osallistumiseen. Niissä on usein tarjolla myös ruoka-apua, sosiaalietuuksia koskevaa ohjausta ja neuvontaa sekä erilaisia jakamistalouden käytäntöjä. (esim. Korhonen ym. 1998.)

Kohtaamispaikkoja on Helsingissä verrattain paljon, mutta niitä koskeva tieto on hajanaista. Yksittäisten toimijoiden ylläpitämistä kohtaamispaikoista on tehty selvityksiä ja tutkimuksia erityisesti päihde- ja mielenterveyspalveluiden osalta (Alanen ym. 2014; Kaakinen ym. 2003; Tedre \& Pulkkinen 2010; Törmä 2007). Valtaosa tutkimuksesta koostuu kuitenkin opinnäytetöistä, joissa on tarkasteltu usein kävijöiden kokemuksia. Vertaisarvioitua tutkimustietoa kohtaamispaikkojen saatavuudesta ja saavutettavuudesta ei tietääksemme ole lainkaan.
Tutkimuksemme tehtävänä on kartoittaa Helsingissä toimivat matalan kynnyksen kohtaamispaikat, joiden kohderyhmänä ovat erityisesti haavoittuvassa asemassa olevat ihmiset. Lähestymme haavoittuvuutta taloudellisen huonoosaisuuden näkökulmasta. Taloudellisen huono-osaisuuden on todettu olevan yhteydessä koettuun osattomuuteen, ja maksuttomilla kohtaamispaikoilla voidaan katsoa olevan erityistä merkitystä juuri niukkuudessa eläville (esim. Isola ym. 2016). Taloudellinen niukkuus korostaa myös kohtaamispaikkojen saavutettavuuden merkitystä (Jolanki ym. 2017; Kivipelto \& Saikkonen 2018; Tuokkola ym. 2016). Keskeinen kysymys on, sijaitsevatko matalan kynnyksen kohtaamispaikat siellä, missä niille oletetaan olevan erityinen tarve. Tutkimme kohtaamispaikkojen sijaintia ja määrää suhteessa sosioekonomiseen niukkuuteen kaupunginosatasolla. Lisäksi tutkimme, missä määrin asukasmäärä, hintataso ja kulkuyhteydet selittävät kohtaamispaikkojen sijaintia kaupunginosissa. Tämä tieto on oleellista esimerkiksi arvioitaessa resurssien kohdentumista tai kehitettäessä palveluita ja toimijoiden välistä yhteistyötä (esim. Never 2011) sekä arvioitaessa yhdenvertaisuuden toteutumista palveluiden saavutettavuudessa (esim. Milligan \& Fyfe 2004). Toistaiseksi kohtaamispaikkatoiminta ei ole lakisääteistä toimintaa, mutta tulevaisuudessa esimerkiksi osallistavan sosiaaliturvan kokeilun pohjalta saattaa nousta uudenlaisia tavoitteita myös kohtaamispaikoille (erilaisista kokeiluista ks. esim. Kivipelto ym. 2018). 
MATALAN KYNNYKSEN

\section{KOHTAAMISPAIKKOJEN TOIMINTAKENTTÄ}

Matalan kynnyksen kohtaamispaikkojen toimintakenttä on moninainen. Niiden toiminnan lähtökohdat ovat yhtäältä erityisryhmien auttamisessa ja tarpeisiin vastaamisessa ja toisaalta asuinalueiden ja niiden asukkaiden hyvinvoinnin edistämisessä ja tukemisessa. Kohtaamispaikkojen juuret voidaan paikantaa kansalais- ja järjestölähtöiseen toimintaan, kristilliseen diakoniatyöhön ja kaupungin aluekehittämistyöhön. Toimintakentälle on kuitenkin luonteenomaista toimijoiden välinen yhteistyö, jossa eri sektoreiden toiminta kietoutuu toisiinsa. Myös toimintaympäristön muutokset ovat muovanneet kohtaamispaikkatoimintaa. Kaikkinensa toiminta on ollut melko vakiintumatonta.

Nykyisen kohtaamispaikkatoiminnan edelläkävijöinä voidaan pitää jo 1800-luvun lopulla syntyneitä raittius-, nuorisoseurain- ja työväentaloja (esim. Maunu ym. 2016) sekä kansainvälisistä esikuvista mallia ottaneiden kristillistaustausten toimijoiden kuten Setlementtiliikkeen ja kaupunkilähetysten toimintamuotoja (Grönlund \& Pessi 2015; Jalovaara 2015; Paaskoski 2017). Erityisesti setlementtitoiminnan keskiössä olivat köyhien kortteleihin perustetut kansalaiskeskukset, joissa vaikeissa tilanteissa olevia haluttiin tukea sekä rohkaista yhteisöllisyyteen ja yhteisten asioiden edistämiseen (Maaperä 2014).

Kansalaislähtöinen toiminta on lähtenyt liikkeelle usein yksittäisten ihmisten halusta ennaltaehkäistä ja auttaa erilaisista sosiaalisista ongelmista kärsiviä (esim. Ruokanen 2018). Toimin- taympäristön paineissa kansalaislähtöinen toiminta on usein organisoitunut, verkostoitunut, ammattimaistunut ja muuttunut lahjoitusten ja avustusten turvin toimivasta vapaaehtoistyöstä osittain myös palveluiden tuottamiseksi (esim. Särkelä 2016). Toiminnan pyrkiessä tavoittamaan etenkin erityisryhmiä ja julkisten palveluiden ulkopuolella olevia vähäosaisia matalan kynnyksen kohtaamispaikat ovat olleet keskeinen lähestymistapa autettavien ihmisten tavoittamisessa ja kohtaamisessa.

1990-luvun lama ja suurtyöttömyys synnyttivät uusia avauksia kohtaamispaikkojen toimintakentällä. Muun muassa nykymuotoinen ruoka-aputoiminta syntyi pitkälti evankelisluterilaisten seurakuntien tuolloin aloittamille yhteisruokailuille ja ruokajakeluille (Karjalainen 2008). Samaan ajanjaksoon ajoittuvat myös ensimmäiset alueelliset asukastalot, joita asukasyhdistykset, paikalliset työttömien yhdistykset ja kaupunki perustivat etenkin vanhoille asuinalueille asukaslähtöisen toiminnan ja kohtaamisen tiloiksi (Korhonen ym. 1998; Savolainen 2013; Saavola \& Kurki 2002). Alun perin asukaslähtöisen toiminnan painopisteen on ajan myötä todettu siirtyneen virallisten tahojen organisoiman projektiluontoisen toiminnan suuntaan (Kopomaa 2013). Työttömien yhdistykset perustivat erityisesti 1990-laman aikana aktiivisesti kohtaamispaikkoja, jotka tarjosivat työttömille monenlaista tekemistä ja omaehtoista toimintaa työllistymisen edistämiseksi (Korhonen ym. 1998). Sittemmin toimijoiden määrä on karsiutunut toimintaympäristön tuottamien muutospaineiden alla, ja myös työttömien yhdistysten toiminnassa on korostunut yhä enemmän julkisten pal- 
veluiden täydentäjän rooli (esim. Halme 2015).

Kaupunki on tukenut asukas- ja työttömien yhdistyksiä kohtaamispaikkojen perustamisessa ja ylläpidossa (Korhonen ym. 1998; Savolainen 2013). Kaupunki on perustanut myös omia lähiöasemia ja asukastaloja osana erilaisia aluekehittämishankkeita (Asumisen rahoitus- ja kehittämiskeskus 2016; Helsingin kaupunki 1999; Helsingin kaupunkisuunnitteluvirasto 2008; Nupponen ym. 2008). Kulttuuriasiainkeskuksen aluetyö perusti ensimmäinen asukastalon Malminkartanoon osana Terve kaupunki 2000 -ohjelmaa (Saavola \& Kurki 2002). Tällä hetkellä sosiaali- ja terveystoimiala hallinnoi Helsingissä kymmentä kaikille avointa asukastaloa, joiden tarkoituksena on toimia asukkaiden olohuoneina ja kokoontumistiloina sekä tarjota asukkaille vaikutuskanavia. Lisäksi sosiaali- ja terveystoimella on erityisryhmille suunnattua kohtaamispaikkatoimintaa, jonka tarkoituksena on tukea asiakkaiden osallisuutta ja elämänhallintaa (päihde- ja mielenterveyskuntoutujien kohtaamispaikat) tai edistää hyvinvointia ja lievittää yksinäisyyden kokemuksia (vanhusten ja työttömien palvelukeskukset). (Helsingin kaupunki 2019.)

Kohtaamispaikoissa käyvät kokevat usein niiden vaikuttavan positiivisesti hyvinvointiinsa, ja kohtaamispaikkoja toivotaan lisää (Haarni 2010; Hokkanen 2014; Jolanki ym. 2017; Pitkänen ym. 2017; Tuokkola ym. 2016; Wallin 2014). Mahdollisuudet mielekkääseen tekemiseen ja muiden ihmisten kohtaamiseen ovat kävijöille tärkeitä. Asukastalojen on koettu tuovan asuinalueille sosiaalista hyvinvointia ja ehkäisevän esimerkiksi turvallisuusongelmien syntymistä lisäämällä paikallista kanssakäymistä, yhteenkuuluvuuden tunnetta sekä tukemalla paikallista identiteettiä (Kopomaa 2013; Korhonen 1998). Esimerkiksi Antti Wallinin (2014) tutkimuksen mukaan kohtaamispaikoissa käyminen luo eläkeläisnaisten arkeen rutiineja ja mahdollistaa sosiaalisen kanssakäymisen samassa elämäntilanteessa olevien kanssa. Kohtaamispaikkojen koetaan vahvistavan myös paikallista yhteenkuuluvuuden tunnetta ja auttavan luomaan ikäihmisten kotona pärjäämistä tukevia sosiaalisia verkostoja. Ehkäisevän päihdetyön kohtaamispaikkojen kävijöille tehdyn kyselyn mukaan merkittävimmät syyt toimintaan osallistumiseen olivat halu tavata ja tutustua uusiin ihmisiin, oppia ja saada tietoa sekä halu auttaa muita ja saada mielekästä tekemistä (Pitkänen ym. 2017). Myös mielenterveyskuntoutujien avoimissa kohtaamispaikoissa tehdyn kyselyn mukaan toiminnassa nähdään tärkeänä erityisesti merkityksellinen tekeminen ja yhdessä oleminen (Hokkanen 2014).

\section{KOHTAAMISPAIKKOJEN SIJAINTIA SELITTÄVÄT TEKIJÄT}

Kohtaamispaikkoja ylläpitävien toimijoiden lähtökohdat poikkeavat toisistaan. Julkisten palveluiden tulee lain mukaan taata esimerkiksi palveluiden riittävyys, kun taas yleishyödyllisten toimijoiden osalta tällaista vaatimusta ei ole. Julkisten palveluiden sijoittumisessa tärkeitä tekijöitä ovat palvelutarpeet, asukasmäärä ja saavutettavuus. Esimerkiksi pääkaupunkiseudun peruspalvelut (päiväkodit, koulut ja terveyspalvelut) keskittyvät tiheästi asutuille aluille ja 
raideliikenteen varteen (Helsingin kaupunki 2013). Väestön ja työpaikkojen sijaintia on aikaisemmissa tutkimuksissa tarkasteltu toisistaan riippuvina tekijöinä. Sijaintiin liittyvä keskinäisriippuvuus (spatial interdependence) on nähty kaupunkia määrittäväksi piirteeksi esimerkiksi asiakkaiden sijainti vetää yrityksiä puoleensa (Papageorgiou \& Thisse 1985). Saman voi olettaa koskettavan myös julkisen ja kolmannen sektorin palvelutoimintaa (ks. esim. Chaston 2011). Toisaalta työvoiman sijainnin on todettu olevan keskeinen tekijä työpaikkojen sijoittumisen kannalta (Deitz 1998).

Helsingin kaupungin virastoissa on käytössä niin sanottuja tarveindeksejä, joiden avulla selvitetään alueiden palvelutarvetta ja suunnitellaan resursointia. Annina Ala-Outisen (2010) tekemän selvityksen mukaan tarveindeksejä on hyödynnetty resurssien jaossa hyvin vähän opetusvirastoa lukuun ottamatta. Aikuissosiaalityön resursoinnissa väestötietoihin perustuvia menetelmiä ei ole käytetty systemaattisesti, vaikka positiivista diskriminaatiota onkin projektiluonteisesti hyödynnetty (Ala-Outinen 2010). Esimerkiksi osa asukastaloista on perustettu osana lähiöprojekteja. Asukastalotoiminta ei kuitenkaan ole lakisääteistä toimintaa, ja niitä on perustettu historiallisesti eri puolille kaupunkia erilaisista lähtökohdista, jolloin verkosto ei välttämättä ole kattava (Korhonen ym. 1998; Saavola \& Kurki 2002; Savolainen 2013).

Kolmannen sektorin toimijoilla ei ole vastuuta yhdenvertaisuuden toteutumisesta palveluiden saatavuudessa, jolloin kohtaamispaikkaverkosto voi olla hajanainen (Smith \& Grønbjerg 2006).
Helsingissä toimivien kohtaamispaikkojen osalta vaikuttaa kuitenkin siltä, että julkinen ja kolmas sektori tekevät paljon yhteistyötä ja täydentävät toisiaan sosiaali- ja terveyspalveluiden tuottamisessa. Kaupunki on ollut aloitteentekijänä esimerkiksi useissa asukastaloissa. Se myös rahoittaa yhdistysten ja järjestöjen toimintaa, vuokraa toimitiloja ja organisoi osaa kohtaamispaikoista yhteistyössä sektoreiden kesken. (Korhonen ym. 1998; Savolainen 2013.)

Toimijoiden sijainti ja sijaintiin vaikuttavien tekijöiden tutkiminen on ollut yksi keskeinen tehtävä kolmannen sektorin tutkimuksessa (esim. Bielefeld 2001). Kolmannen sektorin toiminta on usein organisoitunut jonkin avuntarpeessa olevan ryhmän ympärille, ja teoreettisesti onkin oletettu toimijoiden sijoittuvan sinne, missä avun tarvitsijat ovat (Grønbjerg \& Paarlberg 2001). Useat tutkimukset tukevat tätä näkemystä; erityisesti taloudelliseen hyvinvointiin keskittyvien palveluiden on todettu sijaitsevan useammin huono-osaisilla alueilla eli siellä, missä asukkailla on enemmän palvelutarpeita (esim. Clifford 2012; Peck 2008; Yan ym. 2014). Kaikki tutkimukset eivät kuitenkaan tue tarvehypoteesia (esim. Allard 2004; Grønbjerg \& Paarlberg 2001; Never \& Westberg 2017). Kolmannen sektorin toimijoiden sijaintiin vaikuttaa myös erilaisten resurssien saatavuus. Esimerkiksi työntekijöitä ja vapaaehtoisia löytyy helpommin parempiosaisilta alueilta (Da Costa 2016; Grønbjerg \& Paarlberg 2001).

Hyvä julkinen liikenne puolestaan tuo työvoimaa työpaikan ulottuville (vrt. Deitz 1998; ks. myös Helsingin kau- 
punki 2011) ja helpottaa asiakaskunnan houkuttelemista palvelun piiriin. Toimitilat muodostavat kuitenkin huomattavan osan monien kohtaamispaikkojen kustannuksista (Korhonen ym. 1998), minkä vuoksi voidaan toisaalta olettaa, että niukkojen resurssien kanssa tasapainoilevat kolmannen sektorin toimijat joutuvat hakeutumaan edullisimmille alueille (esim. Milligan \& Fyfe 2004; Never \& Westberg 2017). Kaupungin ylläpitämien paikkojen kohdalla tämä on ehkä vähemmän merkityksellistä, koska kohtaamispaikat toimivat kaupungin omistamissa tiloissa.

Edellä esitetyn pohjalta esitämme seuraavat hypoteesit:

H1: Kaupunginosan taloudellinen huono-osaisuus on positiivisessa yhteydessä kohtaamispaikkojen määrään.

H2: Kaupunginosan asukasmäärä on positiivisessa yhteydessä kohtaamispaikkojen märään.

H3: Kohtaamispaikat sijaitsevat todennäköisemmin hyvien liikenneyhteyksien varrella.

H4: Kaupunginosan hintataso on negatiivisessa yhteydessä kolmannen sektorin kohtaamispaikkojen määrään.

\section{Aineisto JA MENetelmät}

Tutkimuksen aineisto muodostuu Helsingin kaupunginosia koskevasta tilastotiedosta, Helsingissä toimivien matalan kynnyksen kohtaamispaikkojen osoitetiedoista sekä kohtaamispaikkojen työntekijöille suunnatusta kyselystä. Kaupunginosia koskevat tilastotiedot ovat vuodelta 2015, ja ne ovat peräisin Aluesarjat-tietokannasta, tilastoraporteista tai Helsingin kaupunginkanslian kaupunkitutkimus ja -tilastot -yksiköstä. Valitsimme analyysiyksiköksi kaupunginosat, koska ne tarjoavat esimerkiksi peruspiiritasoa tarkemman kuvan alueen sosioekonomisesta tilanteesta ja muodostavat lähiympäristön, jota kohtaamispaikkojen voidaan olettaa palvelevan.

Kartoitimme kohtaamispaikat ja keräsimme niiden osoitetiedot osana tätä tutkimusta. Määrittelimme matalan kynnyksen kohtaamispaikan tietyssä osoitteessa sijaitsevaksi paikaksi, jossa on julkisen tai yleishyödyllisen tahon järjestämää maksutonta toimintaa säännöllisesti vähintään kaksi kertaa viikossa, kohtaamispaikkaan meneminen ei edellytä ennakkoilmoittautumista tai ajanvarausta ja siellä on mahdollisuus muun toiminnan ohella viettää aikaa vapaamuotoisesti toisten ihmisten seurassa (ks. esim. Lund 2008). Etsimme paikkoja, joissa oli maksutonta toimintaa kaikille tai tietyille haavoittuvassa asemassa oleville ryhmille. Näiksi ryhmiksi rajasimme lopulta löydettyjen kohtaamispaikkojen ja aikaisemman tutkimuksen perusteella työttömät, päihde- ja mielenterveysongelmista kärsivät, asunnottomat sekä vankilaista vapautuneet (esim. Keskinen ym. 2009).

Kartoituksessa kävi ilmi, että eläkeläisille suunnatut paikat olivat palvelukeskuksia lukuun ottamatta tyypillisesti auki vain kerran viikossa, joten vain eläkeläisille suunnattuja paikkoja ei ole tarkasteltu tässä tutkimuksessa erikseen, vaikka osa eläkeläisistä onkin haavoittuvassa asemassa. Maahanmuuttajille suunnatut paikat eivät myöskään ole mukana tässä tutkimuksessa, koska niiden toiminnasta oli vaikea löytää tietoa ja lisäksi näemme, että ne tarvitsevat 
selkeästi oman tutkimuksensa. Tutkimuksen ulkopuolelle rajautuivat myös asukasaktiivien varassa toimivat asukastilat, joiden toiminta painottuu tilojen vuokraamiseen eri toimijoille harrastus-, juhla- ja hyötykäyttöön. Nämä tilat voivat kuitenkin olla alueiden asukkaille merkityksellisiä kohtaamisen ja toiminnan paikkoja (ks. Korhonen ym. 1998). tiedoilla. Lisäksi etsimme kohtaamispaikkoja haavoittuvassa asemassa oleville suunnatuista oppaista, sosiaali- ja terveysalan järjestöjen rahoituspäätöksistä sekä relevanttien keskusjärjestöjen ja seurakuntien verkkosivuilta. Lopuksi pyysimme kenttää tuntevia asiantuntijoita arvioimaan listaa. Löysimme yhteensä 69 edellä mainitut kriteerit täyttävää kohtaamispaikkaa. Hakuprosessi ja sen tulokset on esitetty kuviossa 1 .

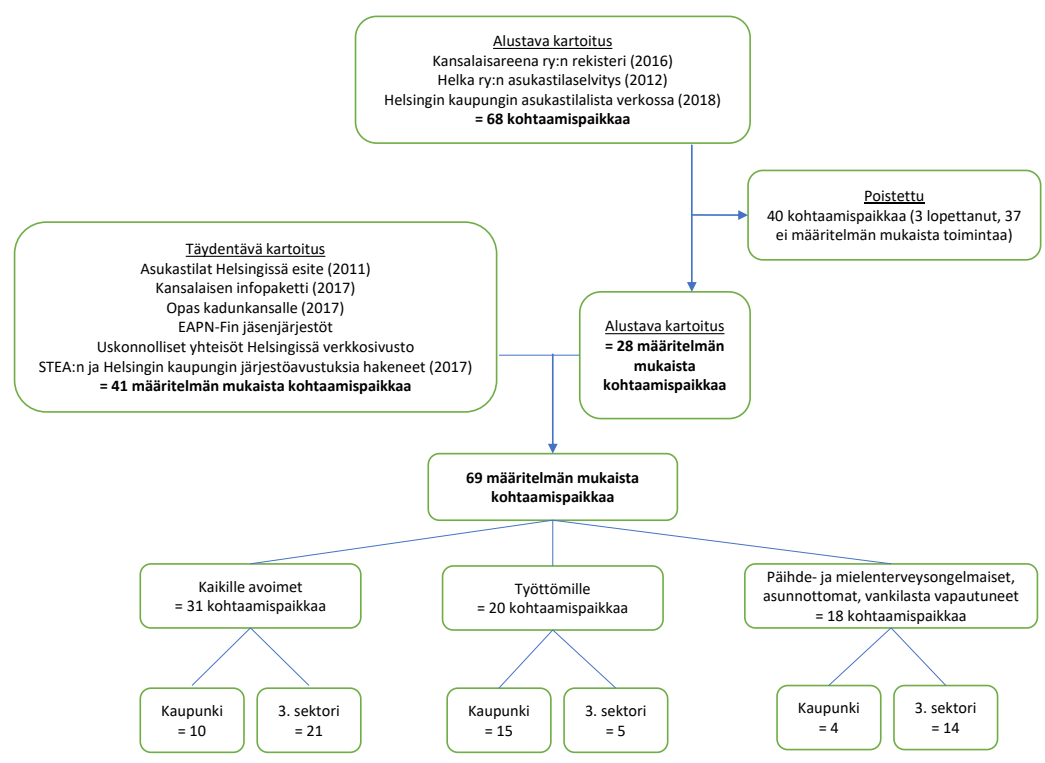

Kuvio 1. Matalan kynnyksen kohtaamispaikkojen kartoitusprosessi sekä kartoituksen tulokset toimijan ja kohderyhmän mukaan

Aloitimme kartoituksen olemassa olevista rekistereistä. Kansalaisareena ry. ylläpitää valtakunnallista kohtaamispaikkarekisteriä, mutta se perustuu toimijoiden omiin ilmoituksiin, eikä ole siten kattava. Täydensimme listaa asukastaloja koskevista selvityksistä ja kaupungin verkkosivuilta löytyvillä
Toimitimme kaikkiin kohtaamispaikkoihin kyselyn, jossa tiedustelimme työntekijöiden käsityksiä kohtaamispaikan sijaintiin vaikuttaneista tekijöistä. 77 prosenttia kyselyn kohdejoukosta vastasi $(\mathrm{n}=53)$. 
Tarkastelimme kohtaamispaikkojen määrää taloudellisen huono-osaisuuden suhteen erilaisissa kaupunginosissa. Kaupunginosien taloudellista huonoosaisuutta mittasimme indeksillä, jonka laskimme järjestämällä kaupunginosat suuruusjärjestykseen pienituloisissa asuntokunnissa asuvien henkilöiden, toimeentulotuesta osallisten henkilöiden sekä työttömien suhteellisten osuuksien perusteella (ks. esim. Stjernberg 2017). Lisäksi tarkastelimme kohtaamispaikkojen määrää suhteessa toimeentulotuesta osallisten henkilöiden määrään taloudellisen huono-osaisuuden suhteen erilaissa kaupunginosissa. Toimeentulotukea pidetään yleisesti taloudellisen huono-osaisuuden mittarina (esim. Kangas \& Ritakallio 2008). Kohtaamispaikat on tarkoitettu hyvin erilaisista syistä haavoittuvassa asemassa oleville ja osa kaikille alueen asukkaille. Taloudellinen huono-osaisuus kuvaa huono-osaisuutta vain osittain, eikä se välttämättä kosketa kaikkia paikkojen kävijöitä.Taloudellinen huono-osaisuus on kuitenkin keskimäärin yleisempää niiden henkilöiden keskuudessa, joita tutkimamme kohtaamispaikat tavoittelevat. Se vaikuttaa myös palvelutarpeeseen ja osallisuuteen.

Kohtaamispaikkojen sijaintia selittäviä tekijöitä tutkimme Poisson-regression avulla, joka soveltuu lukumääräisten vastemuuttujien varianssin selittämiseen (Coxe ym. 2009). Tilastollista merkitsevyyttä arvioimme viiden prosentin riskitasolla. Tarkastelimme ensin muuttujien vakioimattomia päävaikutuksia. Selittävinä muuttujina olivat mainitun taloudellinen huono-osaisuus -indeksin lisäksi sen osatekijät. Osatekijöitä koskevat analyysit esitämme erikseen pienituloisten, toimeentulotuesta osal- listen ja työttömien määrän ja osuuden suhteen. Lisäksi selittävinä tekijöinä tarkastelimme hypoteesien mukaisesti alueiden kulkuyhteyksiä ja hintatasoa. Luokittelimme kaupunginosat Helsingin seudun liikenteen (HSL) runkolinjaston pysäkkien sijainnin mukaan pysäkillisiin ja pysäkittömiin. Analyyseissä vertasimme pysäkittömiä kaupunginosia pysäkillisiin. Kaupunginosien hintatason operationalisoimme vanhojen osakehuoneistojen keskineliöhinnaksi postinumeroalueittain vuonna 2015. Täydessä mallissa käytimme alueen taloudellisen huono-osaisuuden indeksiä, koska yksittäiset taloudellista huonoosaisuutta kuvaavat muuttujat korreloivat voimakkaasti keskenään. Lisäksi aineiston havaintojen määrä on suhteellisen pieni. Selittävät muuttujat on mallinnettu jatkuvina muuttujina lukuun ottamatta liikenneyhteyksiä, joka on kaksiluokkainen.

\section{TulokseT}

Kohtaamispaikkojen käsitykset sijaintiin vaikuttavista tekijöistä

Pyysimme kyselytutkimuksessa kohtaamispaikkojen työntekijöitä valitsemaan annetuista vaihtoehdoista yhden tekijän, joka parhaiten kuvaa sitä, miksi kohtaamispaikka sijaitsee juuri kyseisessä osoitteessa. Vastaukset jakautuivat seuraavasti: sijainti lähellä ihmisiä, joille toiminta on suunnattu (38\%), toimitilojen saatavuus tai omistaminen (32\%), sijainti hyvien liikenneyhteyksien varrella $(25 \%)$ ja sijainti lähellä ihmisten tarvitsemia muita palveluita (4\%). Kaupungin ja kolmannen sektorin kohtaamispaikkojen välillä oli hieman eroja: puolet kaupungin paikoista ilmoitti 
tärkeimmäksi tekijäksi sijainnin lähellä ihmisiä, kun taas kolmannen sektorin kohdalla tämä oli vasta kolmanneksi suosituin vaihtoehto (28 \%). Samoin kaikille avoimet paikat valitsivat sijainti lähellä ihmisiä -tekijän useammin (48 $\%)$ kuin erityisryhmille suunnatut paikat $(27 \%)$, jotka puolestaan valitsivat useammin toimitiloihin ja liikenneyhteyksiin liittyvät tekijät. Hyvät liikenneyhteydet olivat merkityksellisiä erityisesti alueellisille paikoille, joissa kävi ihmisiä eri puolilta kaupunkia.

Kohtaamispaikkojen sijainti ja saatavuus erilaisissa kaupunginosissa: kuvailevat analyysit

Alueiden väestörakennetta kuvaavien muuttujien tunnusluvut on esitetty taulukossa 1. Kuten taulukosta nähdään, neliöhinnan perusteella. Taulukosta 2 nähdään kohtaamispaikkojen sijainnin painottuvan taloudellisen huono-osaisuuden ja suuren asukasmäärän luonnehtimille alueille sekä niille alueille, joissa on HSL:n runkolinjaston pysäkki. Kohtaamispaikkoja on vähiten keskihintaisilla aluilla. Toimijoiden ja kohderyhmän mukaan tarkasteltuna jakaumat ovat samansuuntaiset.

Käytimme edellä mainittua kaupunginosien niukkuusluokitusta ja laskimme, kuinka monta toimeentulotuen saajaa asui kullakin alueella suhteessa kohtaamispaikkojen määrään. Pienimmän suhdeluvun saaneelle luokalle on annettu arvo 1 ja muut luokat on suhteutettu tähän arvoon. Tulokset on raportoitu taulukossa 3.

Taulukko 1. Kaupunginosien $(\mathrm{N}=118)$ väestörakennetta kuvaavien muuttujien

\begin{tabular}{|l|l|l|l|}
\hline Muuttuja & Vaihteluväli & Keskiarvo & Keskihajonta \\
\hline Asukasmäärä & $133-14965$ & 5081 & 3630 \\
\hline Yli 65-vuotiaiden määrä & $0-3190$ & 844 & 714 \\
\hline Pienituloisten määrä & $17-4331$ & 648 & 604 \\
\hline Toimeentulotuen saajat* & $9-2915$ & 588 & 567 \\
\hline Työttömien määrä & $8-1309$ & 332 & 272 \\
\hline
\end{tabular}

${ }^{*}$ Toimeentulotuesta osallisten henkilöiden määrä kaupunginosissa on laskettu vuositasolla, jolloin sama henkilö voi olla tilastossa useamman kerran, jos hän on asunut useammassa kaupunginosassa ja saanut toimeentulotukea.

alueet ovat tarkasteltujen muuttujien osalta varsin erilaisia. Muuttujat myös korreloivat kohtalaisen voimakkaasti (.67-.93).

Tarkastelimme kohtaamispaikkojen sijaintia erilaisilla alueilla ensin suorien jakaumien avulla. Jaoimme kaupunginosat $(\mathrm{N}=118)$ kolmeen lukumääräisesti yhtä suureen luokkaan taloudellinen huono-osaisuus -indeksin, asukasmäärän ja osakehuoneistojen keski-
Taulukosta 3 näemme, että matalan kynnyksen kohtaamispaikkojen saatavuus heikkenee kaupunginosan taloudellisen huono-osaisuuden kasvaessa.Toimijoiden välillä eroa ei juuri ole. Kaikille avoimien kohtaamispaikkojen saatavuus on selkeästi heikoin taloudellisesti huono-osaisimmilla alueilla, kun taas erityisryhmille suunnattujen paikkojen saatavuus on yhtä heikkoa keskimääräisillä ja huonoosaisilla alueilla. 
Taulukko 2. Kohtaamispaikkojen suorat jakaumat (frekvenssit) erilaisissa kaupunginosissa toimijoiden ja kohderyhmän mukaan (suluissa muuttujien luokkien vaihteluvälit)

\begin{tabular}{|l|l|l|l|l|l|}
\hline Muuttuja & $\begin{array}{l}\text { Kaikki } \\
\text { kohtaamispaikat }\end{array}$ & $\begin{array}{l}\text { Kaupungin } \\
\text { paikat }\end{array}$ & $\begin{array}{l}\text { 3. sektorin } \\
\text { paikat }\end{array}$ & $\begin{array}{l}\text { Kaikille } \\
\text { avoimet }\end{array}$ & $\begin{array}{l}\text { Erityisryhmille } \\
\text { avoimet }\end{array}$ \\
\hline $\begin{array}{l}\text { Niukkuus (N=118): } \\
\text { vähän (3-38,33) } \\
\text { keskim. (39,33-73,33) } \\
\text { paljon (74,33-111) }\end{array}$ & 8 & 3 & 5 & 1 & 7 \\
\hline $\begin{array}{l}\text { Asukasmäärä (N=118): } \\
\text { matala (133-2655) }\end{array}$ & 49 & 7 & 5 & 6 & 6 \\
$\begin{array}{l}\text { keskim. (2735-6919) } \\
\text { korkea (6945-14965) }\end{array}$ & 120 & 19 & 30 & 24 & 25 \\
\hline $\begin{array}{l}\text { Hintataso (N=117): } \\
\text { korkea (4530-6728) }\end{array}$ & 48 & 0 & 1 & 0 & 1 \\
keskim. (3243-4512) & 26 & 9 & 11 & 7 & 13 \\
matala (2150-3242) & 16 & 20 & 28 & 24 & 24 \\
\hline $\begin{array}{l}\text { Pysäkki (N=118): } \\
\text { ei }\end{array}$ & 27 & 9 & 17 & 10 & 16 \\
on & 27 & 6 & 10 & 9 & 7 \\
\hline Yhteensä & 14 & 13 & 12 & 15 \\
\hline & 69 & 9 & 18 & 12 & 15 \\
\hline
\end{tabular}

Taulukko 3. Toimeentulotukea saaneiden määrä suhteutettuna kohtaamispaikkojen määrään taloudellisen huono-osaisuuden suhteen erilaisissa kaupunginosissa toimijan ja kohteen mukaan

\begin{tabular}{|l|l|l|l|l|l|}
\hline $\begin{array}{l}\text { Niukkuutta } \\
\text { kuvaava } \\
\text { indeksi } \\
\text { (N=118) }\end{array}$ & $\begin{array}{l}\text { Toimeentulotukea } \\
\text { saaneet/ } \\
\text { Kaikki } \\
\text { kohtaamispaikat }\end{array}$ & $\begin{array}{l}\text { Toimeentulotukea } \\
\text { saaneet/ } \\
\text { Kaupungin } \\
\text { kohtaamispaikat }\end{array}$ & $\begin{array}{l}\text { Toimeentulotukea } \\
\text { saaneet/ } \\
\text { 3. sektorin } \\
\text { kohtaamispaikat }\end{array}$ & $\begin{array}{l}\text { Toimeentulotukea } \\
\text { saaneet/ } \\
\text { Kaikille avoimet } \\
\text { kohtaamispaikat }\end{array}$ & $\begin{array}{l}\text { Toimeentulotukea } \\
\text { saaneet/ } \\
\text { Erityisryhmille } \\
\text { avoimet paikat }\end{array}$ \\
\hline Matala & 1.00 & 1.00 & 1.00 & 1.00 & 1.00 \\
\hline Keskim. & 2.04 & 1.75 & 1.49 & 1.90 & 2.64 \\
\hline Korkea & 2.06 & 2.45 & 2.34 & 3.65 & 2.58 \\
\hline
\end{tabular}

Luvuissa on huomioitu toimeentulotuesta osallisten henkilöiden määrä vain niiden kaupunginosien osalta, joissa on matalan kynnyksen kohtaamispaikka.

Koko kaupungin tasolla tarkasteltuna yhtä kohtaamispaikkaa kohti oli 1099 toimeentulotuen saajaa ja kaikille avointa kohtaamispaikkaa kohti 2447 toimeentulotuen saajaa vuonna 2015. Helsingin kaupunginosista 29 prosenttia on sellaisia, joissa on kaupunginosien mediaania (391 henkilöä) enemmän toimeentulotuesta osallisia henkilöitä mutta ei yhtään kaikille avointa kohtaamispaikkaa.
Kohtaamispaikkojen sijaintia selittävät tekijät

Lopuksi testasimme asetetut hypoteesit Poisson-regressioanalyysin avulla. Testatut mallit, eksponoidut regressiokertoimet, keskivirheet, tilastolliset merkitsevyystasot ja mallien hyvyys on raportoitu taulukossa 4. Sarakkeessa 1 on esitetty muuttujien vakioimattomat päävaikutukset eri vastemuuttujille: kaikki kohtaamispaikat, kaupungin ja 
kolmannen sektorin ylläpitämät paikat sekä kaikille ja erityisryhmille avoimet paikat. Sarake 2 sisältää täydet mallit, joissa on kaikki hypoteesien mukaiset muuttujat. Lisäksi täydessä mallissa on vakioitu yli 65-vuotiaiden osuus alueilla, jolloin pääsemme käsiksi tästä tekijästä puhdistettuun taloudellisen niukkuuden alueelliseen vaihteluun. paikkojen määrä kasvaa 37 prosenttia. Käytännössä malli ennustaisi kohtaamispaikkojen määrän kasvamista 0,14 paikasta 8 paikkaan siirryttäessä määrällisesti pienimmän työttömyyden alueelta suurimman työttömyyden alueelle. Myös kaupunginosan asukasmäärä on positiivisessa yhteydessä kohtaamispaikkojen määrään. Lisäksi kohtaamis-

Taulukko 4. Oletettujen selittävien tekijöiden yhteydet kohtaamispaikkojen määrään kaupunginosissa. Poisson-regressio, regressiokerrointen eksponentit, merkitsevyystasot, keskivirheet sekä mallien hyvyys $(\mathrm{N}=117)$

\begin{tabular}{|c|c|c|c|c|c|c|c|c|c|c|}
\hline \multirow{2}{*}{ Muuttujat } & \multicolumn{5}{|c|}{ Sarake 1: bivariaattimallit } & \multicolumn{5}{|c|}{ Sarake 2: täydet mallit } \\
\hline & Kaikki & Kaup. & 3.sektori & Kaikille & Eritysryh. & Kaikki & Kaup. & 3.sektori & Kaikille & Erityisryh. \\
\hline$+65 \%$ & $\begin{array}{l}1.086^{* *} \\
(0.0252)\end{array}$ & $\begin{array}{l}1.156^{* *} \\
(0.0418)\end{array}$ & \begin{tabular}{|l|}
1.043 \\
$(0.0314)$ \\
\end{tabular} & $\begin{array}{l}1.068(*) \\
(0.0368)\end{array}$ & $\begin{array}{l}1.100 * * \\
(0.0345)\end{array}$ & $\begin{array}{l}1.079 * \\
(0.0333)\end{array}$ & $\begin{array}{l}1.156^{*} \\
(0.0552)\end{array}$ & $\begin{array}{l}1.033 \\
(0.0424)\end{array}$ & $\begin{array}{l}1.046 \\
(0.0492)\end{array}$ & \begin{tabular}{|l|}
$1.107^{*}$ \\
$(0.0453)$
\end{tabular} \\
\hline $\begin{array}{l}\text { Pienituloiset } \\
\text { Pienituloiset\% }\end{array}$ & $\begin{array}{l}1.081 * * * \\
(0.0093) \\
1.035^{* *} \\
(0.0104)\end{array}$ & $\begin{array}{l}1.084^{* * *} \\
(0.0140) \\
1.036^{*} \\
(0.0156)\end{array}$ & $\begin{array}{l}1.078 * * * \\
(0.0126) \\
1.034 * \\
(0.0139)\end{array}$ & $\begin{array}{l}1.082^{* * *} \\
(0.0138) \\
1.034^{*} \\
(0.0158)\end{array}$ & $\begin{array}{l}1.080^{* * *} \\
(0.0127) \\
1.036 * \\
(0.0138)\end{array}$ & & & & & \\
\hline $\begin{array}{l}\text { Työttömät } \\
\text { Työttömät\% }\end{array}$ & $\begin{array}{l}1.369 * * * \\
(0.0339) \\
1.144 * * * \\
(0.0262)\end{array}$ & $\begin{array}{l}1.392 * * * \\
(0.0519) \\
1.156 * * * \\
(0.0403)\end{array}$ & $\begin{array}{l}1.352 * * * \\
(0.0448) \\
1.136 * * * \\
(0.0345)\end{array}$ & $\begin{array}{l}1.400 * * * \\
(0.0501) \\
1.167 * * * \\
(0.0390)\end{array}$ & $\begin{array}{l}1.344^{* * *} \\
(0.0461) \\
1.125^{* *} \\
(0.0355)\end{array}$ & & & & & \\
\hline $\begin{array}{l}\text { Tt.tuki } \\
\text { Tt.tuki\% }\end{array}$ & $\begin{array}{l}1.130 * * * \\
(0.0141) \\
1.072 * * * \\
(0.0161)\end{array}$ & $\begin{array}{l}1.138^{* * *} \\
(0.0214) \\
1.075^{* *} \\
(0.0248) \\
\end{array}$ & $\begin{array}{l}1.123 * * * \\
(0.0188) \\
1.069 * * \\
(0.0213) \\
\end{array}$ & $\begin{array}{l}1.144^{* * *} \\
(0.0205) \\
1.079 * * \\
(0.0239)\end{array}$ & $\begin{array}{l}1.117^{* * *} \\
(0.0196) \\
1.065^{* *} \\
(0.0219)\end{array}$ & & & & & \\
\hline $\begin{array}{l}\text { Niukkuus } \\
\text { indeksi }\end{array}$ & $\begin{array}{l}1.027^{* * *} \\
(0.0047)\end{array}$ & $\begin{array}{l}1.028^{* * *} \\
(0,0073)\end{array}$ & $\begin{array}{l}1.026^{* * *} \\
(0.0061)\end{array}$ & $\begin{array}{l}1.031^{* * *} \\
(0.0073)\end{array}$ & $\begin{array}{l}1.023 * * * \\
(0.0061)\end{array}$ & $\begin{array}{l}1.039 * * * \\
(0.0076)\end{array}$ & $\begin{array}{l}1.034^{* *} \\
(0.0117)\end{array}$ & $\begin{array}{l}1.042 * * * \\
(0.0101)\end{array}$ & $\begin{array}{l}1.044^{* * *} \\
(0.0121)\end{array}$ & $\begin{array}{l}1.036 * * \\
(0.0099)\end{array}$ \\
\hline Asukkaat & $\begin{array}{l}1.024^{* * *} \\
(0.0030)\end{array}$ & $\begin{array}{l}1.027^{* * *} \\
(0.0047)\end{array}$ & $\begin{array}{l}1.023^{* * *} \\
(0.0040)\end{array}$ & $\begin{array}{l}1.025^{* * *} \\
(0.0045)\end{array}$ & $\begin{array}{l}1.024 * * * \\
(0.0041)\end{array}$ & $\begin{array}{l}1.020 * * * \\
(0.0036)\end{array}$ & $\begin{array}{l}1.019 * * \\
(0.0054)\end{array}$ & $\begin{array}{l}1.020 * * * \\
(0.0050)\end{array}$ & $\begin{array}{l}1.022^{* * *} \\
(0.0057)\end{array}$ & $\begin{array}{l}1.018^{* * *} \\
(0.0047)\end{array}$ \\
\hline Hintataso & $\begin{array}{l}0.996 \\
(0.0102)\end{array}$ & $\begin{array}{l}0.981 \\
(0.0168)\end{array}$ & $\begin{array}{l}1.006 \\
(0.0130)\end{array}$ & $\begin{array}{l}0.989 \\
(0.0157)\end{array}$ & $\begin{array}{l}1.002 \\
(0.0135)\end{array}$ & $\begin{array}{l}1.052^{* *} \\
(0.0149)\end{array}$ & $\begin{array}{l}1.047(*) \\
(0.0246)\end{array}$ & $\begin{array}{l}1.057^{* *} \\
(0.0189)\end{array}$ & $\begin{array}{l}1.047^{*} \\
(0.0224)\end{array}$ & $\begin{array}{l}1.057^{* *} \\
(0.0200)\end{array}$ \\
\hline Kulkuyhteys & $\begin{array}{l}0.318^{* * *} \\
(0.2467)\end{array}$ & $\begin{array}{l}0.223^{* * *} \\
(0.4014)\end{array}$ & $\begin{array}{l}0.405^{* *} \\
(0.3178)\end{array}$ & $\begin{array}{l}0.313^{* *} \\
(0.3687)\end{array}$ & $\begin{array}{l}0.323^{* *} \\
(0.3319)\end{array}$ & $\begin{array}{l}0.942 \\
(0.2903)\end{array}$ & $\begin{array}{l}0.670 \\
(0.4801)\end{array}$ & $\begin{array}{l}1.141 \\
(0.3701)\end{array}$ & $\begin{array}{l}1.057 \\
(0.4307)\end{array}$ & $\begin{array}{l}0.851 \\
(0.3942)\end{array}$ \\
\hline $\begin{array}{l}\text { devianssi } \\
\text { df } \\
\text { pseud. } R^{2} \\
\chi^{2}(\text { df) }\end{array}$ & & & & & & $\begin{array}{l}75,077 \\
111 \\
0,567 \\
98,48(5)\end{array}$ & $\begin{array}{l}51,100 \\
111 \\
0,496 \\
50,26(5)\end{array}$ & $\begin{array}{l}66,278 \\
111 \\
0,449 \\
53,90(5)\end{array}$ & $\begin{array}{l}56,287 \\
111 \\
0,458 \\
47,56(5)\end{array}$ & $\begin{array}{l}74,165 \\
111 \\
0,415 \\
52,58(5)\end{array}$ \\
\hline
\end{tabular}

Sarakkeesta 1 näemme, että kaikki taloudellista huono-osaisuutta kuvaavat muuttujat ovat positiivisessa yhteydessä kohtaamispaikkojen määrään. Näistä voimakkain yhteys on työttömyydellä: alueen työttömien määrän kasvaessa sadalla, esimerkiksi kaikkien kohtaamis- paikkoja on epätodennäköisemmin kaupunginosissa, joissa ei ole HSL:n runkolinjaston pysäkkiä verrattuna niihin kaupunginosiin, joissa on pysäkki. Vakioimattomassa mallissa kaupunginosan hintataso ei ole lineaarisessa yhteydessä kohtaamispaikkojen määrään. 
Vakioimattoman mallin tuloksiin tulee kuitenkin suhtautua varauksella muuttujien välisen yhteisvaihtelun vuoksi.

Sarakkeen 2 vakioiduissa malleissa kohtaamispaikkojen määrä kasvaa kaupunginosan taloudellisen huonoosaisuuden lisääntyessä, eli hypoteesi 1 saa vahvistusta. Taloudellinen huonoosaisuus -indeksin kasvaessa yhdellä kaikkien kohtaamispaikkojen määrä kasvaa 3,9 prosenttia. Taloudellista huono-osaisuutta kuvaava indeksi on hieman voimakkaammin yhteydessä kolmannen sektorin kuin kaupungin paikkojen määrään. Huono-osaisuus selittää hieman enemmän myös kaikille avointen paikkojen sijaintia verrattuna eritysryhmille suunnattuihin paikkoihin. Myös hypoteesi 2 saa tukea aineistosta: kaupunginosan asukasmäärä on positiivisessa yhteydessä kohtaamispaikkojen määrään. Esimerkiksi kaikkien kohtaamispaikkojen määrä kasvaa 2 prosenttia asukasmäärän kasvaessa sadalla. Hypoteesi 3 ei saa tukea aineistosta. Oletuksen vastaisesti kaupunginosan hintataso on positiivisessa yhteydessä kolmannen sektorin kohtaamispaikkojen määrään; osakehuoneistojen keskineliöhinnan kasvaessa 100 euroa, kohtaamispaikkojen määrä kasvaa 5,5 prosenttia. Hintataso ei ole valitulla riskitasolla tilastollisesti merkitsevässä yhteydessä kaupungin paikkojen määrään. Myöskään hypoteesi 4 ei saa tukea: kun muiden tekijöiden yhteydet mallissa on vakioitu, kohtaamispaikkoja ei ole enempää kaupunginosissa, joissa on runkolinjaston pysäkki kuin pysäkittömissä. Lopuksi voidaan vielä todeta, että kaupungin ylläpitämiä paikkoja on todennäköisemmin alueilla, joissa ikääntyneiden osuus on suurempi. Vakioitu malli ennusti kaik- kien kohtaamispaikkojen määrän vaihtelevan nollan ja kuuden paikan välillä (ka. 0,59 paikkaa), havaintoaineistossa vaihteluväli oli 0-5 (ka. 0,58).

Arvioimme vaikutusvaltaisten havaintojen osuutta täysien mallien tuloksiin Cookin etäisyyksillä. Vaikka suhteellisesti vaikutusvaltaisimmat tapaukset jätettiin pois, tulokset pysyivät sisällöllisen tulkinnan kannalta pääosin samoina. Kaupungin ja kaikille avoimien paikkojen malleissa asuntojen hinta tuli merkitseväksi vasta, kun vaikutusvaltaisimmat havainnot jätettiin pois. Mallit eivät eronneet tilastollisesti merkitsevästi aineistoon parhaiten sopivista malleista, ja mallit vähensivät devianssia tilastollisesti merkitsevästi tyhjään malliin verrattuna (ks. esim. Coxe ym. 2009).

\section{Pohdinta}

Olemme kartoittaneet tässä tutkimuksessa Helsingissä toimivat matalan kynnyksen kohtaamispaikat ja selvittäneet niiden sijaintiin liittyviä tekijöitä. Erityisesti pitkittyneeseen taloudelliseen huono-osaisuuteen liittyy haasteita, joiden nähdään lisäävän lähellä sijaitsevien ja maksuttomien toimintamahdollisuuksien merkitystä (Isola ym. 2017; Kissaine 2010; Kivipelto \& Saikkonen 2018).

Tuloksemme tukevat tarvehypoteesia, sillä kohtaamispaikat sijaitsevat useammin alueilla, joissa asuu enemmän pienituloisia, työttömiä ja toimeentulotukea saavia. Julkisen ja kolmannen sektorin paikat eivät tässä suhteessa näytä eroavan toisistaan. Myös useimpien kohtaamispaikkojen työntekijät 
arvioivat sijainnin lähellä kohderyhmää olevan merkittävin kohtaamispaikan sijaintia määrittävä tekijä.

Toisaalta suhteessa taloudellisesti huono-osaisten määrään kohtaamispaikkoja oli vähemmän suhteellisesti huonoosaisemmilla alueilla kuin suhteellisesti parempiosaisilla alueilla. Tämä on linjassa kansainvälisten tutkimusten kanssa, joiden mukaan palvelut eivät useinkaan riitä tasaamaan hyvä- ja huono-osaisten alueiden eroja palvelujen saatavuudessa, vaikka niitä olisikin enemmän huonoosaisilla alueilla (esim. Hasenfeld ym. 2013; Joassart-Marcelli \& Wolch 2003; Peck 2008). Vaikka kohtaamispaikat sijaitsevat useammin taloudellisesti huono-osaisemmilla alueilla, niihin voi kohdistua enemmän tarpeita ja niiden saatavilla olevat resurssit saattavat olla heikommat kuin parempiosaisilla alueilla sijaitsevien.

Oletuksemme vastaisesti kolmannen sektorin kohtaamispaikkojen määrä kasvoi hieman alueen hintatason noustessa. Kansainvälisten tutkimusten mukaan kolmannen sektorin toimijoilla on taipumusta siirtyä kalliimmille alueille toimijan taloudellisen tilanteen parantuessa (Never \& Westberg 2017), mikä voi liittyä esimerkiksi tietynlaisen imagon tavoitteluun (esim. Pfeffer 1982) tai hakeutumiseen muiden toimijoiden ja hyödyllisten resurssien läheisyyteen (esim. Da Costa 2016). Tämän tutkimuksen perusteella emme voi varmuudella sanoa, miksi hintataso on yhteydessä kohtaamispaikkojen määrään. Todennäköisesti taustalla on erilaisia tekijöitä, eivätkä toimijat aina pysty vaikuttamaan kohtaamispaikan sijaintiin. Hakeutuminen muiden toimijoiden läheisyyteen mainittiin ky- selytutkimuksessamme vain harvoin tärkeimpänä sijaintiin vaikuttaneena tekijänä. Erityisesti kolmannen sektorin toimijat mainitsivat usein toimitilojen saatavuuden ja omistamisen. Näin vastanneet toimipaikat sijaitsivat kuitenkin useammin halvemmilla alueilla. Sen sijaan liikenneyhteyksien merkitystä painottaneet kohtaamispaikat sijaitsivat kalliimmilla alueilla.

Erityisesti alueellisesti toimivat kohtaamispaikat, joiden kävijäkunta tulee eri puolilta kaupunkia, näkivät hyvät liikenneyhteydet sijaintia ensisijaisesti määrittäväksi tekijäksi. Kohtaamispaikkoja näyttikin olevan useammin kaupunginosissa, joissa oli HSL:n runkolinjaston pysäkki. Vakioidussa mallissa liikenneyhteydet eivät kuitenkaan olleet enää tilastollisesti merkitsevä selittäjä. Tämä selittyy kulkuyhteyksien yhteydellä mallin muihin muuttujiin. Kaupunginosat, joissa on runkolinjaston pysäkki, ovat keskimäärin väestömäärältään suurempia, hintatasoltaan edullisempia ja niissä on suhteellisesti enemmän taloudellista niukkuutta kuin pysäkittömissä kaupunginosissa.

Määrän ohella kohtaamispaikkojen saatavuus konkretisoituu sisäänpääsyn ehdoissa (esim. ikärajat, päihteettömyys) sekä esimerkiksi kävijäkunnan, maineen ja identiteetin tuottamissa kynnyksissä (Törmä 2007). Näitä tarkentavia näkökohtia ei ollut mahdollista tarkastella tutkimusasetelmamme ja aineistomme puitteissa. Emme ole myöskään tarkastelleet kohtaamispaikkojen osallisuustyön sisältöjä tai määrää (esim. aukioloajat), jotka myös määrittävät osallisuustyön saatavuutta ja mielekkyyttä. Lisäksi tutkimamme kohtaamispaikat ovat vain osa osalli- 
suustyön kokonaisuutta. Tutkimuksessa rajauduimme sosiaali- ja terveyspalveluihin, koska olimme kiinnostuneita erityisesti haavoittuvassa oleville suunnatuista paikoista. Näin ollen mukana ei ole esimerkiksi kaupungin kirjastoja, leikkipuistoja, nuorisotiloja tai perhetaloja, jotka ovat monille kaupunkilaisille tärkeitä maksuttomia ajanviettoja kohtaamispaikkoja (ks. esim. Kytö ym. 2011). Jatkossa kohtaamispaikkojen sijaintia voitaisiinkin tarkastella vähemmän järjestelmälähtöisesti esimerkiksi ottamalla lähtökohdaksi kaupunkilaisten määritelmät osallisuudesta ja siihen liittyvistä tarpeista (esim. Närhi ym. 2014).

Olemme tässä tutkimuksessa tarkastelleet kaupungin ja kolmannen sektorin toimijoiden organisoimia kohtaamispaikkoja monilta osin yhdessä. Osallisuustyö ja sen tekeminen yhteistyössä järjestöjen kanssa yleistyy julkisen sektorin toiminnassa (Isola ym. 2017; STM 2015). Järjestöt edustavat kuitenkin julkisesta sektorista erillistä toimintakenttää, jonka keskeisiin lähtökohtiin lukeutuvat toiminnan autonomisuus ja osallistujien omaehtoinen toiminta. Osallisuuden näkökulmasta on tärkeää tunnistaa ja tutkia myös yhteiskunnan eri sektoreiden omaan toimintalogiikkaan liittyviä osallisuuden mahdollisuuksia ja haasteita, joita ei tässä tutkimuksessa pystytty laajemmin ottamaan huomioon.

Tutkimuksemme tuottama tieto on oleellista arvioitaessa resurssien kohdentumista ja kehitettäessä osallisuutta tukevia palveluita ja toimijoiden välistä yhteistyötä (esim. Never 2011). Tulostemme perusteella huomiota tulisi kiinnittää erityisesti alueisiin, jotka ovat vailla kohtaamispaikkaa ja joissa taloudellista huono-osaisuutta on sekä absoluuttisesti että suhteellisesti paljon. Toisaalta kohtaamispaikkoja puuttuu myös alueilta, joilla on absoluuttisesti paljon mutta suhteellisesti vähemmän huono-osaisia. Helsingissä toteutetun sekoittamispolitiikan seurauksena myös suhteellisesti parempiosaisilla alueilla asuu määrällisesti paljon huono-osaisia ihmisiä. Nämä alueet ovat saaneet huono-osaisempia alueita vähemmän huomiota. Liikkuvuus oman asuinalueen ulkopuolelle saattaa muodostua kynnykseksi (Kivipelto \& Saikkonen 2018). Haasteita asettavat myös parempiosaisilla alueilla asuvien asenteet haavoittuvassa asemassa oleville suunnattuja paikkoja kohtaan (ns. NIMBY ilmiö). Erilaisten ihmisten yhteen saattaminen ja sosiaalisen etäisyyden kaventaminen ei ole yksinkertaista, ja ihmiset viihtyvät usein kaltaistensa seurassa (Isola ym. 2016; Korhonen ym. 1998; Kytö ym. 2011). Perustamalla kohtaamispaikkoja lisää parempiosaisille alueille sosiaalista etäisyyttä voitaisiin kuitenkin pyrkiä kaventamaan. Samoin voitaisiin edistää näillä alueilla asuvien ja haavoittuvassa asemassa olevien osallisuutta kaupunkitilasta.

\section{Rahoitus}

Tämä tutkimus on toteutettu Jane ja Aatos Erkon säätiön tuella (Helsinkimissio ry:n ja Helsingin yliopiston Kaupunkilainen köyhyys tänään -hanke 2017-2019). 


\section{KIRJALlisuUs}

Alanen, Olli \& Kainulainen, Sakari \& Saari, Juho (2014) Vamos tekee vaikutuksen. Vamos-nuorten hyvinvointikokemukset ja tulevaisuuden odotukset. Helsinki: Helsingin diakonissalaitos.

Ala-Outinen, Annina (2010) Hyvinvoinnin tukiverkko koetuksella. Helsingin palveluverkostojen toiminta kaupunginosien eriytymisen ehkäisemiseksi. Helsinki: Helsingin kaupungin tietokeskus.

Allard, Scott (2004) Access to social services: The changing urban geography of poverty and service provision. Survey series. Washington: The Brookings Institution.

Asumisen rahoitus- ja kehittämiskeskus (toim.) (2016) Tutkitusti parempi lähiö - asuinalueiden kehittämisohjelman tutkimusjulkaisu. Helsinki: Asumisen rahoitus- ja kehittämiskeskus.

Bielefeld, Wolfgang (2001) The geography of nonprofit sectors. Teoksessa Neil Smelser \& Paul Bates (toim.) International encyclopedia of the social and behavioral sciences. Amsterdam: Elsevier, 10688-10691. https://doi.org/10.1016/ B0-08-043076-7/02554-7

Blomgren, Sanna \& Karjalainen, Jouko \& Karjalainen, Pekka \& Kivipelto, Minna \& Saikkonen, Paula \& Saikku, Peppi (2016) Sosiaalityö, palvelut ja etuudet muutoksessa. Helsinki: Terveyden ja hyvinvoinnin laitos.

Chaston, Ian (2011) Public Sector Management. Mission Impossible? Basingstoke: Palgrave MacMillan. https://doi. org/10.1007/978-0-230-34494-5

Clifford, David (2012) Voluntary sector organisations working at the neighborhood level in England: Patterns by local area deprivation. Environment and Planning 44, 1148-1164. https://doi. org/10.1068/a44446

Coxe, Stefany \&West, Stephen \& Aiken, Leona (2009) The analysis of count data: A gentle introduction to poisson regression and its alternatives. Journal of Personality Assessment 91 (2), 121-136. https://doi. org/10.1080/00223890802634175

Da Costa, Marcelo (2016) What influences the location of nonprofit organizations?
A spatial analysis in Brazil.Voluntas 27 (3), 1064-1090. https://doi.org/10.1007/ s11266-016-9682-7

Deitz, Richard (1998) A joint model of residential and employment location in urban areas. Journal of Urban Economics 44 (2), 197-215. https://doi. org/10.1006/juec.1997.2067

Elonen, Noora \& Niemelä, Jukka \& Saloniemi, Antti (2017) Aktivointi ja pitkäaikaistyöttömien monenlainen toimijuus. Janus 25 (4), 280-296.

Grønbjerg, Kirsten \& Paarlberg, Laurie (2001) Community variation in the size and scope of the nonprofit sector: Theory and preliminary findings. Nonprofit and Voluntary Sector Quarterly 30 (4), 684-706. https://doi. org/10.1177/0899764001304004

Grönlund, Henrietta \& Pessi, Anne Birgitta (2015) Giving in Finland: The multidimensional role of giving in a context of a changing welfare model. Teoksessa Pamala Wiepking \& Femida Handy (toim.) The Palgrave Handbook of Global Philanthropy. Lontoo: Palgrave Macmillan, 155-169. https://doi. org/10.1057/9781137341532_10

Haarni, Ilka (2010) Eläkeläisten kohtaamispaikat tekemisen ja tapaamisen yhteisöinä. Gerontologia 1, 3-13.

Halme, Jyrki (2015) Työttömien yhdistykset Suomessa - Opportunistiset strategiat selviytymiskeinona. Kansalaisyhteiskunta 1,28-50.

Hasenfeld, Yaheskel \& Chen, Mindy \& Garrow, Eve \& Parent, Bill (2013) Spread thin: Human services organizations in poor neighbourhoods. Los Angeles: University of California Regents.

Helsingin kaupunki (1999) Helsingin lähiöprojekti 1996-1999. Arvio toiminnasta ja tavoitteiden saavuttamisesta. Helsinki: Helsingin kaupunki.

Helsingin kaupunki (2019) https://www. hel.fi/helsinki/fi Luettu 30.5.2019

Helsingin kaupunki (2013) Helsingin palveluverkkoselvitys sekä tavoiteverkko 2050. Helsingin kaupunkisuunnitteluviraston yleissuunnitteluosaston selvityksiä 10. https://www.hel.fi/hel2/ksv/julkaisut/yos_2013-10.pdf Luettu 10.7.2018.

Helsingin kaupunki (2011) Pääkaupunkiseudun työpaikka-alueiden saavu- 
tettavuus joukkoliikenteellä. Helsingin kaupunki: kaupunkisuunnitteluvirasto. https://www.hel.fi/hel2/ksv/julkaisut/ yos_2011-19.pdf Luettu 10.7.2018.

Helsingin kaupungin sosiaali- ja terveysvirasto. https://www.hel.fi/static/sote/ asukastoiminta/julkaisut/news-17-1.pdf Luettu 24.7.2018

Helsingin kaupunkisuunnitteluvirasto (2008) Lähiöprojektin toimintakertomus 2007. Helsinki: Helsingin kaupunkisuunnitteluvirasto.

Hokkanen, Liisa (2014) Mielenterveysaktiivien toiminta. Kysely Mielenterveyden keskusliiton jäsenyhdistysten aktiivitoimijoille. Rovaniemi: Lapin yliopisto.

Isola, Anna-Maria \& Turunen, Elina \& Hiilamo, Heikki (2016) Miten köyhät selviytyvät Suomessa? Yhteiskuntapolitiikka 81 (2), 150-160.

Isola, Anna-Maria \& Kaartinen, Heidi \& Leemann, Lars \& Lääperi, Raija \& Schneider, Taina \& Valtari, Salla \& KetoTokoi, Anna (2017) Mitä osallisuus on? Osallisuuden viitekehystä rakentamassa. Helsinki: Terveyden ja hyvinvoinnin laitos.

Jalovaara,Ville (2015) Älä jätä ihmistä yksin. HelsinkiMissio 130 vuotta. Helsinki: Kirjapaja.

Joassart-Marcelli, Pascale \& Wolch, Jennifer (2003) The intrametropolitan geography of poverty and the nonprofit sector in southern California. Nonprofit and Voluntary Sector Quarterly 32 (1), 70-96. https://doi. org/10.1177/0899764002250007

Jolanki, Outi \& Leinonen, Emilia \& Rajaniemi, Jere \& Rappe, Erja \& Räsänen, Tiina \& Teittinen, Outi \& Topo, Päivi (2017). Asumisen yhteisöllisyys ja hyvä vanhuus. Valtioneuvoston selvitysja tutkimustoiminnan julkaisusarja 4 . Helsinki:Valtioneuvosto.

Kaakinen, Juha \& Törmä, Sinikka \& Huotari, Kari \& Inkeroinen, Tiia (2003) Ray:n rahoittaman huumeiden vastaisen työn ja matalan kynnyksen palvelujen merkitys. Ray:n avustustoiminnan raportteja 10. Helsinki: Sosiaalikehitys Oy.

Kangas, Olli \& Ritakallio,Veli-Matti (2008) Köyhyyden mittaustavat, sosiaaliturvan riittävyys ja köyhyyden yleisyys Suomessa. Sosiaali- ja terveysturvan selosteita 61 .
Helsinki: Kela.

Karjalainen, Jouko (2008) Nälkä-äläkästä Nälkäryhmään - tutkimus, ruokapankit ja politiikka lehdistössä. Teoksessa Sakari Hänninen \& Jouko Karjalainen \& KirsiMarja Lehtelä \& Tiina Silvasti (toim.) Toisten pankki: Ruoka-apu hyvinvointivaltiossa. Helsinki: Stakes, 69-114.

Karjalainen, Jouko \& Saikku, Peppi (2016) Kokemuksia osallistavasta sosiaaliturvasta. Selvitys pilottihankkeista vuonna 2014. Helsinki: Terveyden ja hyvinvoinnin laitos.

Keskinen, Vesa \& Laine, Markus \& Tuominen, Martti \& Hakkarainen, Tyyne (toim.) (2009) Kaupunkiköyhyyden monet kasvot. Näkökulmia helsinkiläisten huono-osaisuuteen. Helsinki: Helsingin kaupungin tietokeskus.

Kissaine, Rebecca (2010) "We call it the Badlands": How social-spatial geographies influence social service use. Social Service Review 84 (1), 3-28. https://doi.org/10.1086/652988

Kivipelto, Minna \& Karjalainen, Pekka \& Jokela, Merita \& Liukko, Eeva \& Ilmakunnas, Ilari \& Moisio, Pasi (2018) Osallistavan sosiaaliturvan kuntakokeilu. Tutkimuksesta tiiviisti 31. Helsinki: Terveyden ja hyvinvoinnin laitos.

Kivipelto, Minna \& Saikkonen, Paula (2018) Hyvinvointia niukkuudesta? Kokemuksia viimesijaisesta turvasta. Janus 26 (1), 57-72. https://doi.org/10.30668/ janus. 65291

Kopomaa, Timo (2013) Minne menet asukastalo? Tapausesimerkkejä Helsingistä ja Maunulasta.Työpaperi. Helsingin yliopisto. https://helda.helsinki.fi/bitstream/ handle/10138/40802/Asukastalot_2013_Kopomaa.pdf? sequence $=1$ Luettu 27.5.2018.

Korhonen, Erkki \& Malin, Liisa \& Saavola, Kaarina (1998) Helsingin asukastalot ja yhteiskerhotilat. Tutkimuksia 1. Helsinki: Helsingin kaupungin tietokeskus.

Kytö, Hannu \& Väliniemi-Laurson, Jenni \& Tuorila, Helena (2011) Hyvillä palveluilla laadukkaaseen lähiöasumiseen. Helsinki: Kuluttajatutkimuskeskus.

Leemann, Lars \& Hämäläinen, Riitta-Maija (2016) Asiakasosallisuus, sosiaalinen osallisuus ja matalan kynnyksen palvelut - pohdintaa käsitteiden sisällöstä.Yhteis- 
kuntapolitiikka 81 (5), 586-594.

Lund, Pekka (2008) Päihdetyön päiväkeskus. Katoava työmuoto vai tärkeä osa palveluketjua. Helsinki: Sininauhaliitto.

Maaperä, Ilona (2014) Hautautuneen elämän herättelyä? Suomalaisen setlementtiliikkeen hegemoninen kansansivistystoiminta 1920-1939. Vapaan sivistystyön tutkijatapaaminen Varkaudessa 28.29.8.2014 http://www.sivistystyo.fi/ doc/tutkimustyopaja2014/Maapera_Ilona.pdf Luettu 24.4.2019.

Maunu, Antti \& Sironen, Jiri \& Äyräs, Liisa \& Sattilainen, Riitta (toim.) (2016) Elokolo - kohtaamispaikkatoiminnan käsikirja. Helsinki: Ehyt ry.

Milligan, Christine \& Fyfe, Nicholas (2004) Putting the voluntary sector in its place: Geographical perspectives on voluntary activity and social welfare in Glasgow. Journal of Social Policy 33 (1), 73-93. https://doi.org/10.1017/ S0047279403007268

Mäntyneva, Päivi \& Hiilamo, Heikki (2018) Osallisuuden ja osattomuuden dynamiikka työtoiminnassa. Etnografinen tutkimus kolmella kuntouttavan työtoiminnan kentällä.Yhteiskuntapolitiikka 83 (1), 18-28.

Never, Brent (2011) The case for better maps of social service provision: Using the holy cross dispute to illustrate more effective mapping. Voluntas 22 (1), 174188. https://doi.org/10.1007/s11266010-9123-y

Never, Brent \& Westberg, Drew (2017) Moving to need: The effect of federal contracts on service provider location. Nonprofit Political Forum 8 (2), 147164. https://doi.org/10.1515/npf-20170008

Nupponen, Terttu \& Broman, Eeva-Liisa \& Korhonen, Erkki \& Laine Markku (toim.) (2008) Myönteisiä muutoksia ja kasvavia haasteita. Kokemuksia Helsingin lähiöprojektin v. 2004-2007 ja Urban II -yhteisöaloiteohjelman v. 2001-2006 toiminnasta. Tutkimuksia 6. Helsinki: Helsingin kaupungin tietokeskus.

Närhi, Kati \& Kokkonen, Tuomo \& Matthies, Aila-Leena (2014) Asiakkaiden osallisuus ja työntekijöiden harkintavalta palvelujärjestelmässä. Janus 22 (3), 227-244.

Paaskoski, Jyrki (2017) Ihmisen arvo. Por- voo: Edita Publishing.

Papageorgiou, Yorgos \& Thisse, JaquesFrançois (1985) Agglomeration as spatial interdependence between firms and households. Journal of Economic Theory 37 (1), 19-31. https://doi. org/10.1016/0022-0531(85)90028-6

Peck, Laura (2008) Do antipoverty nonprofits locate where people need them? Evidence from a spatial analysis of Phoenix. Nonprofit and Voluntary Sector Quarterly 37 (1), 138-151. https://doi. org/10.1177/0899764006298963

Pfeffer, Jeffrey (1982) Organizations and Organization Theory. Boston: Pitman.

Pitkänen, Tuuli \& Jokelainen, Suvi \& Sironen, Jiri \& Glad, Timo (2017) Matalan kynnyksen kohtaamispaikat edistävät hyvinvointia. Katsauksia ja näkökulmia 1. Helsinki: A-klinikkasäätiö.

Raivio, Helka \& Karjalainen, Jarno (2013) Osallisuus ei ole keino tai väline, palvelut ovat! Teoksessa Taina Era (toim.) Osallisuus - oikeutta vai pakkoa. Jyväskylä: Jyväskylän ammattikorkeakoulu.

Ruokanen, Tapani (2018) Kun huumeet tulivat Helsinkiin - Vihreän keitaan tarina. Jyväskylä: Docendo.

Saavola, Kaarina \& Kurki, Hannu (2002) Asukastalot ja yhteiskerhotilat 2002 . Asukastalojen ja asuinalueiden kehitysprosesseja. Helsinki: Helsingin Asukastaloverkostoyhdistys HATY ry. / Helsingin kaupunginosayhdistysten liitto ry. HELKA.

Saikku, Peppi (2018) Valtion ja kuntien vastuunjako pitkäaikaistyöttömien aktivoinnissa - Sisällönanalyysi hallitusohjelmista ja hallituksen esityksistä vuosina 19952015. Janus 26 (2), 104-122. https://doi. org/10.30668/janus. 65466

Savolainen, Päivi (2013) Katsaus helsinkiläisiin asukastiloihin 2012. Helsingin kaupunginosayhdistykset ry. http:// helka.net/images/stories/tiedostot/katsaus_helsinkilaisiin_asukastiloihin_2012. pdf Luettu 27.5.2018

Smith, Steven \& Grønbjerg, Kirsten (2006) Scope and theory of government-nonprofit relations. Teoksessa Walter Powell \& Richard Steinberg (toim.) The nonprofit sector. A research handbook. New Haven:Yale University Press, 221-242.

Sosiaali- ja terveysministeriö (2015) Osal- 
listava sosiaaliturva. Työryhmän loppuraportti. Sosiaali- ja terveysministeriön raportteja ja muistioita 20. Helsinki: Sosiaali- ja terveysministeriö.

Stjernberg, Mats (2017) Helsingin seudun 1960- ja 1970-lukujen lähiöiden sosioekonominen ja demografinen kehitys vuoden 1990 jälkeen. Tutkimuksia 1 . Helsinki: Helsingin kaupunki.

Särkelä, Riitta (2016) Järjestöt julkisen kumppanista markkinoiden puristukseen. Sosiaali- ja terveysjärjestöjen muutos sosiaalipalvelujen tuottajana vuosina 1990-2010. Helsinki: Ensi- ja turvakotien liitto.

Tedre, Silva \& Pulkkinen, Anneli (2010) Palvelu, johon köyhyys tiivistyy: Tutkimus kristillisen päihdetyön päiväkeskuksista. Diakonian tutkimus 2,115-142.
Tuokkola, Kati \& Nieminen, Jarmo \& Konttajärvi, Tiina (2016) Kotoa muiden seuraan. Asuinalue- ja talokohtaisten yhteistilojen arviointi ikääntyneiden näkökulmasta. Helsinki:Ympäristöministeriö.

Törmä, Sinikka (2007) Huono-osaisimmat huumeiden käyttäjät matalan kynnyksen päiväkeskuksessa. Janus 15 (2), 133-148.

Wallin,Antti (2014) Ikääntyvä kerrostalolähiö ja sen eläkeläisnaiset. Yhteiskuntapolitiikka 79 (5), 509-520.

Yan, Jun \& Guo, Chao \& Paarlberg, Laurie (2014) Are nonprofits antipoverty organizations located where they are needed? A spatial analysis of the greater Hartford region. The American Statistician 68 (4), 243-252. https://doi.org/10.1080/0003 1305.2014.955211 